\title{
Skam må bekjempes med kunnskap og holdninger
}

\author{
TV-aksjonen NRK gikk i år til Nasjonalforeningen for folkehelsens arbeid med demens. Søndag 20. oktober \\ gikk årets aksjon av stabelen, og målet var å bidra til åpenhet og forståelse og å bryte ned tabuer og myter.
}

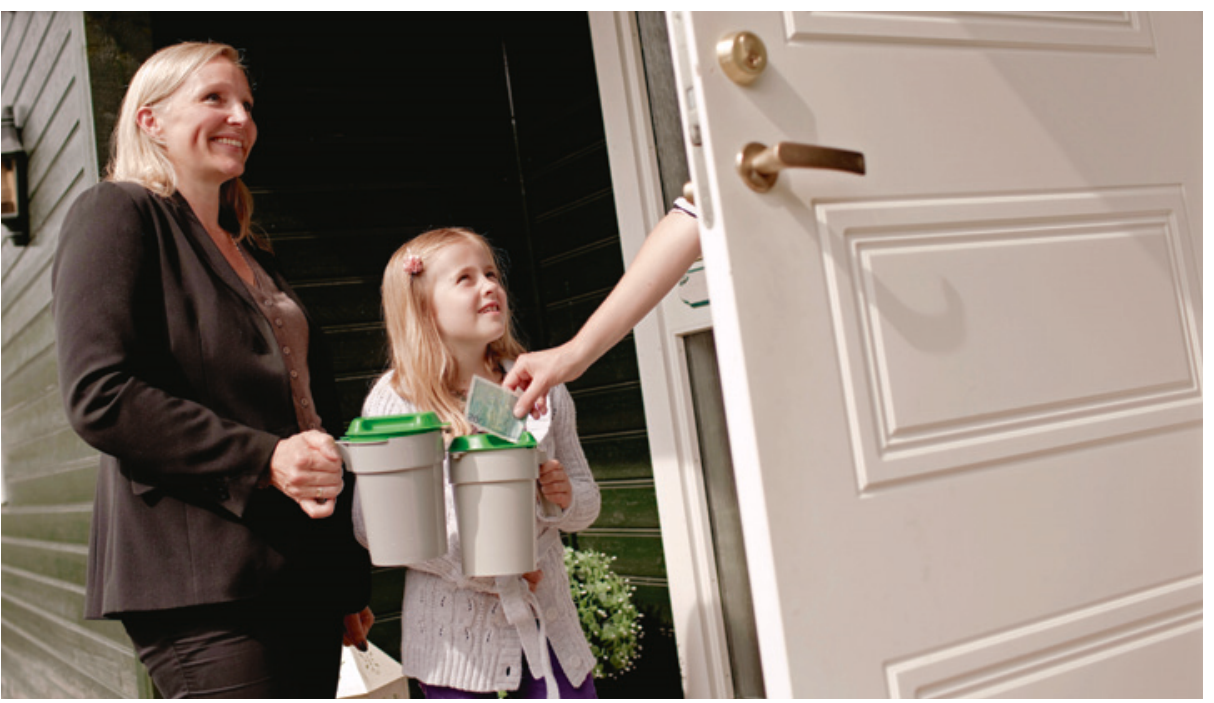

Både voksne og de litt yngre bidro som bøssebærere under årets tv-aksjon. Foto: Stian Lysberg Solum/Scanpix
Lisbet Rugtvedt

lisbet.rugtvedt@nasjonalforeningen.no

Lisbet Rugtvedt (f. 1967) er generalsekretær i Nasjonalforeningen for Folkehelsen, som er årets mottaker av TV-aksjonen på NRK.

\section{PUBLISERT I BLOGGEN}

(6) 16.10. 2013

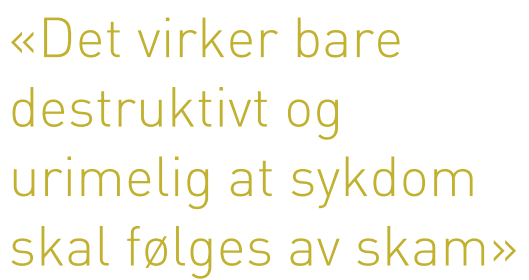

De siste årene har vi fått mer åpenhet om sykdommer som kreft og psykiske lidelser, mens det fortsatt er mye skam, tabuer og mangel på åpenhet rundt demens. Dette legger en ekstra byrde til en diagnose som i seg selv er tung å bære. Åpenhet betyr færre bortforklaringer, mer erfaringsutveksling og felleskap. Ifølge en spørreundersøkelse Nasjonalforeningen for folkehelsen har gjennomført, mener over halvparten av de spurte at demens er forbundet med skam.

Det er ille at en sykdom som kan ramme hvem som helst - og som rammer rundt $20 \%$ av åttiåringer, over $40 \%$ av nittiåringer og mange tusen mennesker som er yngre enn dette - skal oppleves som skamfullt. Skam og fortielse blir en tilleggsbelastning. Over 70000 mennesker i Norge har Alzheimers sykdom eller en annen demenssykdom. I løpet av de neste tiårene vil antallet fordobles.

\section{Hvor kommer skammen fra?}

Store norske leksikon beskriver skam som «sterkt ubehagelig følelse av å ha vist en nedverdigende side av seg selv, og dermed avslørt seg selv som et mislykket, udugelig eller umoralsk individ. Skam er nær knyttet til selvfølelsen, og får en til å føle seg liten, med ønske om å skjule seg («synke i jorden»). Skam gjør det vanskelig å opptre konstruktivt, men kan disponere for aggresjon rettet mot en selv eller tilfeldige andre.»
Noe av dette ligger tett opptil hvordan personer med demens og deres pårørende beskriver opplevelsen av å ha demenssykdom, selv om det er mange sider av deres tilværelse. Det er forståelig at det for eksempel gradvis å miste hukommelse og orienteringssans, går ut over selvfølelsen og skaper «synke i jorden-situasjoner» både for den som er syk og for pårørende. At mange lever lenge med demenssymptomer uten en klar diagnose, slik mange opplever, kan forsterke problemet med skam. Å få en skikkelig forklaring på alt man plutselig ikke mestrer, beskrives av de fleste som en lettelse. Trolig letter det også på skamfølelsen.

Det er interessant og treffende når Store Norske Leksikon skriver at skam «gjør det vanskelig å opptre konstruktivt». Det virker bare destruktivt og urimelig at sykdom skal følges av skam. Sykdom burde følges av forståelse, støtte og omsorg.

\section{Hva kan vi gjøre?}

For å hjelpe personer med demens, slik at flere kan oppleve god livskvalitet og verdighet, må vi bekjempe den lite konstruktive skammen. Vi kan forske oss frem til bedre sykdomsbekjempelse. Skam må bekjempes med kunnskap og holdninger. I møtet med pårørende og helsepersonell hører vi mange historier om mennesker som er svært svekket av demens, men som i glimt viser at de har tanker, følelser, minner og ferdigheter. Det er sterke påminnelser om at ingen må gis opp og at alle må behandles med respekt og verdighet hele livet. Dette er et ansvar for helsepersonell, men det er også et holdningsspørsmål i samfunnet. Det gjelder menneskeverd og menneskerettigheter for mennesker i en sårbar situasjon.

\section{Årets TV-aksjon}

Koker vi dette ned, får vi essensen av hvorfor vi ønsket en TV-aksjonen om demens. TV-aksjonen var en dugnad for mer åpenhet og forståelse, for et innhold i dagene som kan gi mer verdighet til personer med demens. En dugnad for et samfunn som er mer romslig mot dem som ikke mestrer alt like godt som før.

Ønsket vårt var å bidra til å komme noen steg nærmere en løsning av demensgåten. Om det ble små eller store steg, kan vi egentlig ikke vite ennå. For en dag finner noen muligens en liten puslebrikke som viser seg å være akkurat den som manglet i forståelsen av hvorfor for eksempel Alzheimers sykdom oppstår.

Kommentarer til og diskusjoner om innlegget finner du på blogg.tidsskriftet.no Vil du blogge, ta kontakt. 